\title{
The family and the state: a public choice perspective
}

\author{
Clara E. Piano ${ }^{1}$
}

Accepted: 4 January 2022 / Published online: 22 February 2022

(c) The Author(s), under exclusive licence to Springer Science+Business Media, LLC, part of Springer Nature 2022

\begin{abstract}
The family is an institution within which exchange takes place. The state depends on the productivity of families for its current and future revenues. Yet, work on family policy often ignores the role of local knowledge, incentives, and special interests, while families themselves are often overlooked in accounts of the unintended consequences of public policy. The work of Julian Simon is a notable exception. Building upon his insights about the family's production of children in particular, this paper offers a way to think about family policy that is consistent with both family economics and public choice. I conclude by applying some basic principles to better understand three patterns: the gap between intended and actual fertility in the developing world today, the lack of successful pro-natal public policy, and the oscillation of totalitarian family policy.
\end{abstract}

Keywords Family policy · Public choice $\cdot$ Family economics · Julian Simon · Austrian economics

JEL Codes $\mathrm{H} 00 \cdot \mathrm{J} 11 \cdot \mathrm{J} 13$

\begin{abstract}
Many thanks to my husband, Ennio Piano, for inspiring the original idea behind this paper during our conversations in graduate school. I am also indebted to Peter Jacobsen for introducing me to the work of Julian Simon and to Louis Rouanet for his helpful comments during the editing process. Finally, thanks to the F.A. Hayek Program at the Mercatus Center for providing the four of us with desk spaces which happened to be next to each other.
\end{abstract}

Clara E. Piano

cjace@samford.edu

1 Samford University, Homewood, AL, USA 


\section{Introduction}

"The family may fairly be considered, one would think, an ultimate human institution. Every one would admit that it has been the main cell and central unit of almost all societies hitherto, except, indeed, such societies as that of Lacedaemon, which went in for 'efficiency,' and has, therefore, perished..."

- G.K. Chesterton

Since Bastiat, economists have prided themselves on seeing the "unseen" forces which shape and guide society. This goal, however, is hampered when there are trade barriers within the discipline. The "unseen" which family economics tries to bring to light - exchange within the family - and the "unseen" investigated by public choice - exchange within the state - too often run parallel to one another. A coherent theory of family policy is missing.

Anyone can see that these two institutions have an important relationship. State revenues depend on the productivity of families as well as firms. Mandatory spending - in areas tradi- tionally in the purview of families like elderly care and children's education - amounted to 12.9\% of United States GDP in 2019 (CBO). Courts have increasingly defined and regulated familial relationships, a phenomenon Brinig (2000) refers to as the lifting of the "marital veil." Recent work documents significant "Kuznets facts" for the family throughout the stages of economic development (Greenwood et al., 2021). Still, the relationship between families and states is not well understood.

This paper does not offer a complete theory of family policy, but it does suggest a way to begin: an increase in trade between the fields of public choice and family economics. As it stands, much of the work on family policy fails to take public choice insights - such as the potential for unintended consequences, knowledge and incentive problems, and the role of special interests - into account. The canonical textbook that introduces students to the field of public choice, Public Choice III (Mueller, 2003), does not contain an entry for the term "family." There are, of course, notable exceptions. Foremost amongst them is the work of Julian Simon on population growth.

Building upon many of Simon's insights, I work towards a theory of family policy by focusing on three principles: 1) families produce people, 2) people produce ideas, and 3) familial production occurs privately. State actors exhibit an interest in family policy because their revenues are impacted by population growth and the growth of ideas, though their interests may diverge from family members because of the third principle. I test this approach by applying it to three patterns in family policy:

1. A fertility gap exists across most countries today, indicating that couples are not able to complete their fertility plans.

2. Family policy has historically been very successful at lowering fertility rates, but largely unsuccessful at increasing them.

3. Central planners of economic life tend to be central planners of family life as well. 
I find that considering the public choice aspects of family policy can help explain these patterns, and hopefully, caution against future proposals for public intervention in family life.

As Gary Becker is recognized for his foundational research in family economics, Julian Simon deserves recognition for his work on family and population policy. ${ }^{1}$ I count it as no co- incidence that Simon naturally incorporated public choice insights in his approach to family and population policy, since he was a scholar in the mainline tradition of economics. Because of his lifetime work, those wishing to understand the complex relationship between the family and the state can now look to an example.

\section{Background}

\subsection{Family economics}

In their pioneering contribution to family economics, Becker and Murphy (1988) write:

We believe that a surprising number of state interventions mimic the agreements that would occur if children were capable of arranging for their care. Stated differently, our belief is that many regulations of the family improve the efficiency of family activities (p. 1)

If this is correct, then family policy is a rather unique area. It would seem to be protected from the usual knowledge and incentive problems that these same economists have often pointed out in other areas (Becker et al., 2006, 2011; Murphy \& Topel, 2006). But this is unconvincing, since knowledge and incentive problems are likely to be the largest when states intervene upon the smallest, most private organization in society - the family. Still, we might dismiss these concerns if families were not important for the overall productivity of society. Yet the evidence overwhelmingly indicates that families play a critical role in determining a variety of economic and social outcomes, such as poverty (Lerman, 1996; Peterson, 1987), human capital (Doyle et al., 2013), social mobility (Chetty et al., 2018), and political values (Jennings \& Niemi, 1968; Wolfinger \& Wolfinger, 2008).

While the field of family economics has progressed since the work of Becker, many of its underlying assumptions about the state remain unchanged. In addition to postulating benevolence, three key insights from public choice have yet to be incorporated: 1) knowledge and incentive problems, 2) unintended consequences, and 3) the role of special interests. Simplifying various aspects of reality are, of course,

\footnotetext{
1 There are, of course, many who do recognize Simon's contributions and have devoted time and efforts at introducing them to a broader audience. Amongst such scholars are Don Boudreaux (Boudreaux, 2008, 2011), Paul Dragos Aligica (Aligica, 2009), Byran Caplan and Art Carden (Caplan, 2011), and Peter Jacobsen (Jacobsen, 2020). The Simon Abundance Index that was recently started by Human Progress and the Cato Institute also deserves mention: https://www.humanprogress.org/the-simon-abund ance-index-2020/.
} 
always necessary, but the extent to which state action has been simplified by family economists is no longer warranted given the advances in other economic fields, namely, public choice.

\subsection{Public choice}

Just as family economics has yet to incorporate the contributions of public choice, public choice has scarcely begun to acknowledge the family. Young fields may be excused from foreseeing all their implications, though the continual expansion of family policy has made family a pressing issue, as demonstrated, for example, by Hall (2014) on the moderating role of the family in politics. There are two primary ways in which public choice has neglected the family: 1) not accounting for family effects when it comes to cataloguing the unintended consequences of policy, and 2) leaving the role of special interests in family policy undocumented.

This is not to say that public choice scholars have paid no attention to the family - rather, an unpublished manuscript by James Buchanan reveals his interest in the economic approach to marriage. ${ }^{2}$ It is evident from this brief essay, "Marriage and Opportunity Cost," that Buchanan thought it especially important that the new field of family economics did not stray from the "fundamental principles" of economics. ${ }^{3}$ This paper picks up where Buchanan left off, by applying the fundamental principles of economics, which include public choice, to the area of family policy.

\subsection{Exceptions}

I have argued that family economics and public choice could gain from increased trade. However, scholars within the mainline economic tradition have been an exception, naturally approach- ing family policy with a more consistent framework. Horwitz (2015) is a primary example of a Hayekian approach to family life, as is the work of Kasun (1978, 1988, 1997, 1999). For instance, Kasun (1997) begins her study of the subsidized family-planning industry by noting how:

Austrian economics has long understood that government subsidies of private activities distort incentives, encouraging recipients to use and/or provide more of the services than would otherwise be the case, and to devote resources to lobbying for the protection and promotion of the services (p. 47).

She goes on to identify basic errors in a series of studies claiming that government subsidies for contraception, sterilization, and abortion reduce reliance on public assistance. Kasun (1997) confirms the economic intuitions about moral hazard, showing that: "higher expenditures on government-subsidized birth control are associated with higher ratios of unwed births, higher rates of teenage pregnancy, and

\footnotetext{
2 Another exception to this is Leeson and Pierson (2017) on the economic causes of no-fault divorce, although the authors have trouble identifying a special interest group.

3 The Appendix contains a transcription of Buchanan's brief manuscript.
} 
higher levels of dependency" (p. 70). Though evidenced by the case of subsidies for population reduction, her basic theory also indicates that subsidies for increased population growth would similarly distort incentives.

Research on school choice has also avoided overly simplistic assumptions about political actors and institutions. One reason might be the existence of a clearlydefined special interest group: teachers unions. For example, DeAngelis and Makridis (2020) studies school openings during the COVID-19 pandemic and find that school districts in locations with stronger teachers' unions are less likely to reopen in person, even controlling for differences in local demographic characteristics. Agostinelli et al. (2020) is another such example, documenting how school closures during the COVID-19 pandemic have the most negative impacts on the children in low income neighborhoods. Classic papers in school choice (Hoxby, 2003) as well as recent work (Pakaluk, 2021) highlight how current education policy in the United States suffers from knowledge and incentive problems when it comes to improving educational outcomes for children.

\subsection{Julian Simon as an example}

No scholar so consistently combined the insights of family economics and public choice as did Julian Simon. For instance, Simon (1993) overviews the intellectual history of population control, noting how it was used as a tool for state interests (including Keynes's rejection of Malthus once he realized that population growth stimulated aggregate demand). The references in (Simon, 1993) to Hayek are of special interest:

Friedrich Hayek (1989) recently published important work on the very-longrun evolu- tionary effects of population growth upon cultural patterns. The reason for mentioning this work in a historical survey is that Hayek harbored these ideas for half a century, and they are implicit in his discussion of the market as a discovery process (1960, early chapters); he refrained from publishing these ideas because he did not know of empirical evidence that contradicted the conventional wisdom that population growth has negative effects in the intermediate and long run.

Simon was the one to provide such empirical evidence. In a matching footnote, Simon expands on the correspondence between himself and Hayek - correspondence that "means more to me than anything else that anyone has written about my work," on this issue. ${ }^{4}$ Though he (to my knowledge) never took a course on public choice or family economics, Simon's personal involvement in development projects

\footnotetext{
4 As Hayek wrote: "I have never before written a fan letter to a professional colleague, but to discover that you have in your Economics of Population Growth provided the empirical evidence for what with me is the result of a life-time of theoretical speculation, is too exciting an experience not to share it with you. The upshot of my theoretical work has been the conclusion that those traditional rules of conduct (esp. of several property) which led to the greatest increases of the numbers of the groups practicing them leads to their displacing the others..."
} 
aimed at lowering fertility convinced him deeply that those involved in population control do not always have the interests of families in mind, if only through lack of knowledge. ${ }^{5} \mathrm{He}$ applied this understanding to three main areas connected to family policy: population control, immigration, and government propaganda concerning both.

For the purposes of this paper, the most important argument made by Simon, found in Simon (1977) and his subsequent works, is that policies aimed at reducing the number of people in a country are not only harmful to families, but ultimately detrimental to economic growth. Simon was not naive; he recognized that an additional person implies higher costs in the short run, even if there are unseen, greater benefits in the long run. In his own words:

The real population problem, then, is not that there are too many people or that too many babies are being born. The problem is that others must support each additional person before that person contributes in turn to the well-being of others (Simon, 1996). ${ }^{6}$

It is from this insight that this paper begins to build a theory of family policy.

\section{Toward a theory of family policy}

There is, of course, a fundamental unity across all fields of economics. Boettke and Lopez (2002) emphasize that public choice, as a field, simply applies the economic way of thinking to political processes. Moreover, they point out that "Mises is arguably the first scholar to champion a unification of the social sciences by way of a common rational choice model" (Boettke \& Lopez, 2002, p. 111). A theory of family policy informed by both family economics and public choice would retain this commitment to methodological individualism, exchange via institutions, and rational choice as understood by the mainline tradition.

More specifically, there is a natural overlap in the interests of family economics and pub- lic choice. Families (whether domestic or foreign) are the source of labor in society. Simon is again notable for highlighting the connections between policies aimed at population control and immigration throughout his life's work. Families

\footnotetext{
5 The preface to Simon's magnum opus, Simon (1996), tells the story of the moment he realized that the population control policies he and others were pushing had little or no empirical or theoretical basis: "What business do I have trying to help arrange it that fewer human beings will be born, each one of whom might be a Mozart or a Michelangelo or an Einstein-or simply a joy to his or her family and community, and a person who will enjoy life?"

6 The preceding paragraphs are included for further context: "For the first decades of its life, an additional child certainly is a burden not only on its parents but also on others. Brothers and sisters must do with less of everything except companionship. Taxpayers must cough up additional funds for schooling and other public services... Just as surely, however, an additional person is also a boon. The child or immigrant will pay taxes later on, contribute energy and resources to the community, produce goods and services for the consumption of others, and make efforts to beautify and purify the environment. Perhaps most significant for the more-developed countries is the contribution that the average person makes to increasing the efficiency of production through new ideas and improved methods" (Simon, 1996).
} 
are also major investors in the human capital of their members (Becker, 1981; Buckles \& Munnich, 2012; Doyle et al., 2013). Moreover, two organizational features of the family are mimicked by states: the redistribution of income and the provision of public goods. Breton (1989) provides an interesting discussion of how these functions of the family have increasingly been overtaken by states. Lastly, the family has at least two explicit ties to the political order: its ability to act as an interest group, and its contribution to social order, or in other words, the legibility of the population (Scott, 2020).

The connections between the family and the state can be summarized as follows:

1. Families increase state revenues:

- As the source of labor

- As the primary investor in human capital

2. Families compete with the state:

- As a producer of public goods

- As a distributor of income

3. Families exchange with the state:

- As an interest group

- As the basis of social order

A general theory of family policy would account for all of these. However, the many links between the family and the state prohibit a satisfying analysis within the confines of a single paper. For example, consider how thoroughly one could investigate the interest-group potential of families. ${ }^{7}$ At first glance, each family is diverse and contains members with a wide variety of interests. It seems strange to imagine families lobbying for more state funds to be allocated toward families per say (although some universal basic income proposals pretend to do this). On the other hand, the ascendance of family policy itself might be explained by the interest group activities of family members qua family members (Gauthier, 1996). Policies such as child tax credits, Social Security, and public education unite the diverse interests of families. Put differently, the public choice analysis proposed by this paper could be read as a cautionary tale for family members seeking political benefits.

\footnotetext{
7 I thank two anonymous reviewers for insights on the following points.
} 
What counts as family policy? A de facto definition is needed, since economists want to know how individuals are affected in their everyday lives. Certainly, nearly all public policies have some impact on family life. For the purposes of this paper, I define family policy as any policy that impacts the exchange between family members as family members. While minimum wage legislation may upset families by decreasing the hours of work available to a single mother or the job opportunities for a high school student, it cannot be said to impact these individuals as family members per say (i.e., because they are family members). However, laws that regulate child care will directly impact the exchange between parents and their children, and thus such a policy qualifies under my definition. Of course, the traditional area of family policy - dealing with divorce, child support, and other such legislation - clearly fall within this description as well.

\subsection{Three principles}

To tie public choice and family economics together, I present three principles which could be used to undergird a theory of family policy. The first principle is that families produce people. This is their foremost contribution to societies and also the primary reason that state actors would be interested in regulating familial production. Simon (1996) adds a crucial insight regarding the specifics of this production process:

But we can agree that there is still a population problem, just as there is a problem with all good investments. Long before there are benefits, we must tie up capital that could otherwise be used for immediate consumption.

The organizational structure of the family facilitates the sacrifice of labor in one generation for an increase in labor for the next. More generally, the family is an institution which minimizes transaction costs between its members. From the state's perspective, population growth means relatively lower productivity in the short run but relatively higher productivity in the long run. This can become a problem if those giving up the short-run revenues are not expecting to reap the benefits of population growth the long run. As Buchanan and Wagner (1977) points out, the time horizons of policymakers, bureaucrats, and family members may be very different. The fact that fertility can be viewed as an intergenerational investment project means that the costs and benefits of an additional person will vary depending on the time horizon taken into account.

The second principle is that population growth produces more ideas and innovation Simon (1996). Not only is the "production" of people a process of diversification, but the problems caused by additional people are also an impetus toward innovation. Within the context of a market economy, good ideas can be translated into new technologies and products which make everyone better off (Holcombe, 2009). While families may bear the majority of costs and enjoy the majority of benefits, the added possibility of technological progress extends the "boon" of an additional 


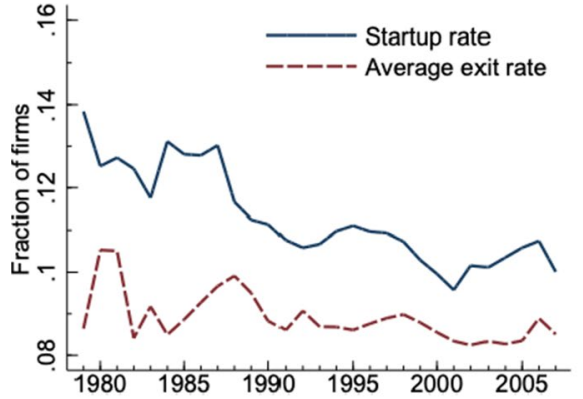

(a) Startup and average exit rates

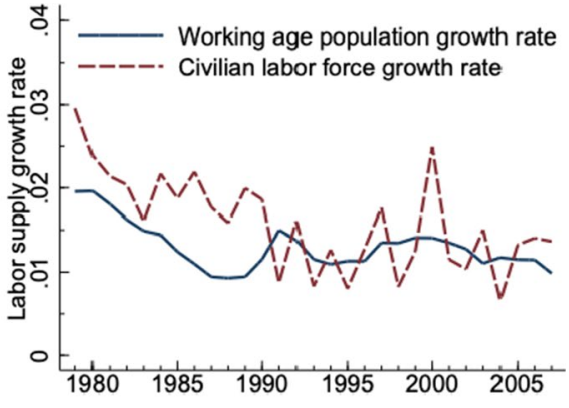

(b) Labor supply growth rates

Fig. 1 Trends in Firms and Labor Supply from 1979 to 2012. Source: Fig. 1 in Karahan et al. (2019).

person to society. The institutions beyond the family will determine the magnitude of this effect. ${ }^{8}$

In a free society, the costs of raising children are largely internalized by the family. With the expansion of government, however, the range of parties affected by the fertility decisions of couples is extended. This principle is also consistent with economic research that points out the dangerous effects of a declining population on standards of living (Jones, 2020). For example, Karahan et al. (2019) find that declining labor supply growth since the late 1970s explains about two-thirds of the decline in the startup rate in the United States. Figure 1 documents these trends.

Additionally, Liang et al. (2018) and Derrien et al. (2020) provide evidence that firms located in younger populations produce more innovation than companies working with a relatively older labor force.

The third principle is that people production occurs privately. ${ }^{9}$ From the mainline per- spective, the locality of this decision-making is a feature - those with the knowledge necessary to make the optimal fertility decisions are the parents themselves (Hayek, 1945). Or, as Simon (1996) argued more explicitly: "The contention that poor and uneducated people breed without constraint is demonstrably wrong." Thus, even minor subsidies or regulations regarding fertility may distort parental incentives in unpredictable ways, since children are indivisible and may ex- hibit nonlinear costs and benefits, i.e., the cheaper by the "dozen" effect (Holmes and

\footnotetext{
${ }^{8}$ As in Simon (1996): "Which is more weighty, the burden or the boon? That depends on the economic conditions and institutions, which we shall discuss at some length. But also, to a startling degree, the decision about whether the overall effect of a child or migrant is positive or negative depends on the values of whoever is making the judgment-your preference to spend a dollar now rather than to wait for a dollar-plus-something in twenty or thirty years, your preferences for having more or fewer wild animals alive as opposed to more or fewer human beings alive, and so on. Population growth is a problem, but not just a problem; it is a boon, but not just a boon. So your values are all-important in judging the net effect of population growth, and deciding whether there are too many or too few people.".

${ }^{9}$ I focus on the production of children in this section, but these principles apply equally to the other things produced within families - insurance, economies of scale, companionship, etc. - which Becker (1981) calls "Z-goods.".
} 
Tiefenthaler, 1997; Lino et al., 2014). However, from the perspective of the state, a family may produce a quantity or "quality" of children that is undesirable. State actors may have preexisting policy commitments that make the marginal child more/ less costly than otherwise would be the case. It is when the couple and the state diverge in their willingness to sacrifice the necessary capital and labor for an additional child that conflicting plans arise. The state is no longer furthering family interests, but rather, has an incentive to use family policy to achieve different goals.

\subsection{Three patterns}

The effects of family policy are still not well understood. At least three patterns emerge from historical and contemporary experience:

1. A fertility gap exists across many countries today, indicating that couples are not able to complete their fertility plans.

2. Family policy has historically been successful at lowering fertility rates, but it has been unsuccessful at increasing them.

3. Central planners of economic life tend to centrally plan family life as well.

First, a fertility gap, which measures the divergence between fertility intentions and com- pleted fertility, exists across most countries in the world today. For example, Beaujouan and Berghammer (2019) use a cohort approach in which women aged 20-24 were asked about their intended family size and then this number was compared to their completed cohort fertility at age 40-42 to document the fertility gap. They also calculate rates of "excess childlessness," in which they compare the number of women aged 20-24 uninterested in having children to those ending up childless at ages 40-42. Their results for excess childlessness across the U.S. and Europe are shown in Figure 2.

While Beaujouan and Berghammer (2019) only report responses from a survey of women, not men, this fact might actually bias their fertility gap findings downward. For example, Doepke and Kindermann (2019) report that women in low-fertility countries are more likely to disagree to having another child than men.

Second, the historical cases of pro-natal policy appear remarkably ineffectual when com- pared to those of anti-natal policy. This in itself is evidence that the connection between families and states is extremely complex. Table 1 records family allowances relative to the average male manufacturing wage across select countries, from 1949-1975, with corresponding fertility rates.

There is no clear relationship between family allowances and fertility, either within country or across countries. Russia provides one of the longest case studies given its history of interventionist family policy beginning in the Soviet era. Figure 3 provides estimates of the Russian population from 1895 and projected through 2045. Ediev (2001) compares this to a "no disturbances" scenario where wars, famines, and other strife from the Soviet period are absent.

Even though the USSR's pronatalist policies began in the 1930-40s with Stalin's monthly payments to "Heroine Mothers," it is evident that Soviet policies aimed at 


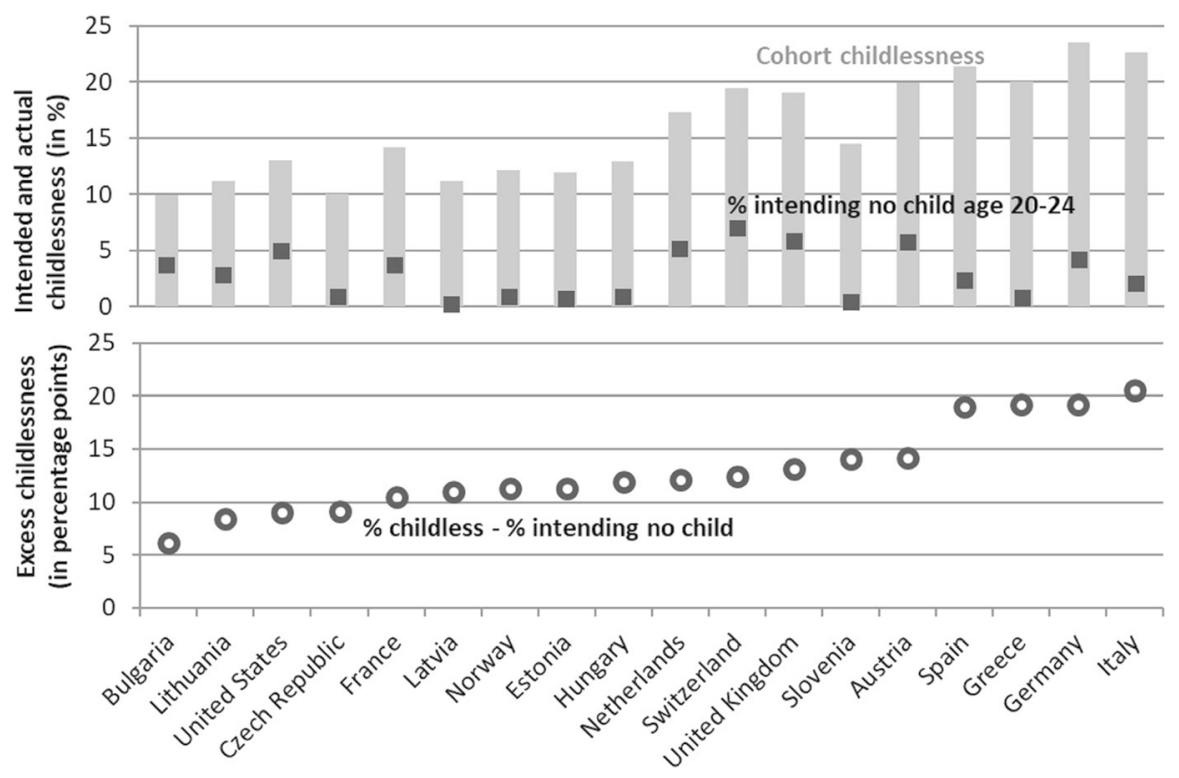

Fig. 2 Share of Women Intending not to have Children at age 20-24, Compared to the Share not having Children at age 40-42. Source: Fig. 1 in (Beaujouan \& Berghammer, 2019, p. 525).

Table 1 Family Allowances for a Two-Child Family and Fertility Rates, 1949-1975

\begin{tabular}{|c|c|c|c|c|c|c|c|}
\hline \multirow[t]{2}{*}{ Country } & \multicolumn{4}{|c|}{ Allowances as $\%$ of male wages $*$} & \multicolumn{3}{|c|}{ Fertility** } \\
\hline & 1949 & 1961 & 1970 & 1975 & 1960 & 1970 & 1975 \\
\hline England and Wales & $3.9 \%$ & $2.9 \%$ & $3.5 \%$ & $2.7 \%$ & 2.68 & 2.4 & 1.78 \\
\hline France & $18.7 \%$ & $13.2 \%$ & $7.5 \%$ & $5.5 \%$ & 2.73 & 2.48 & 1.93 \\
\hline Germany & - & - & $2.2 \%$ & $6.7 \%$ & 2.37 & 2.02 & 1.45 \\
\hline Japan & - & - & - & - & 2.01 & 2.13 & 1.91 \\
\hline Sweden & $9.6 \%$ & $6.4 \%$ & $6.1 \%$ & $5.1 \%$ & 2.17 & 1.94 & 1.78 \\
\hline United States & - & - & - & - & 3.61 & 2.48 & 1.77 \\
\hline
\end{tabular}

*The average manufacturing wage for males. **Fertility refers to the average number of children per woman. "-" indicates no monthly allowance program in place during this period

Source: Tables 4.4 and 7.1 in Gauthier (1996)

increasing fertility were ineffectual. Moreover, population decline is a pressing issue for Russia today; Frejka and Zakharov (2013) overviews Russia's pronatalist policy packages from 1981 to 2007, concluding that "continued population decline in Russia is almost inescapable" (p. 644).

Finally, central planners of economic life tend to be central planners of family life as well. Consider the major central planning agencies in recent history: the Communist Party of the Soviet Union (CPSU), the Chinese Communist Party (CCP), and international development agencies like USAID, the World Bank, and the International Monetary Fund (IMF). Without exception, each of these 


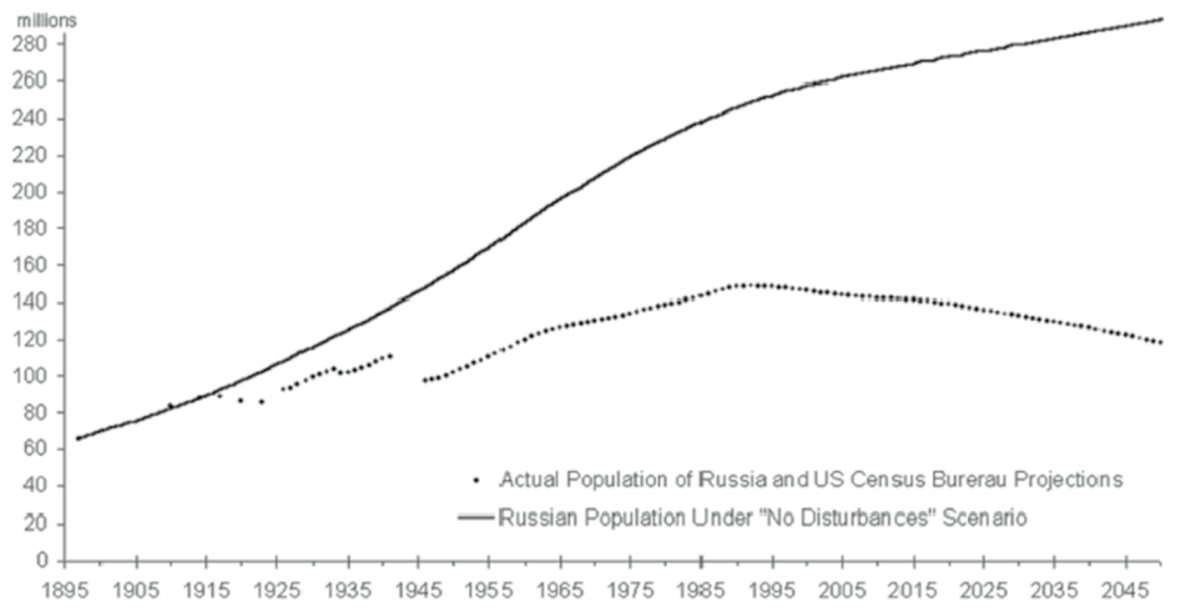

Fig. 3 Russian Population Trends vs. a "no disturbances" Scenario. Source: Fig. 6 in Ediev (2001)

organizations has been or is still committed to population control. For example, a well- cited paper from the World Bank (Lakshminarayanan, 2007) called for a revival of interest in finding strategies "to achieve sustainable reductions in fertility... and build a consensus view in which unsustainably high fertility is once again included in discussions with governments" (p. 3). Moreover, the report admits that:

The main reason for not using contraception in many high-fertility countries in Sub-Saharan Africa is a desire to have more children, rather than unawareness about fer- tility control or lack of access to contraception. Therefore, interventions that aim to lower fertility in Sub-Saharan African countries will need to address the high demand for children (Lakshminarayanan, 2007, p. 16) (emphasis added).

This situation is later referred to as a "motivation issue" (Lakshminarayanan, 2007, p. 28). Without the insights of public choice and Julian Simon, is not immediately clear why individuals in these organizations would have population goals that diverge from the desires and plans of family members themselves.

\section{Accounting for patterns in family policy}

The framework presented in this paper, building on the work of Julian Simon, identified three principles for thinking about family policy: 1) families produce people, 2) people have ideas, and 3) familial production occurs privately. I now apply these principles in the context of three case studies below, demonstrating how combining insights from public choice and family economics can help to explain the observed patterns in family policy. 


\subsection{Pattern 1}

\section{A fertility gap exists across many countries today, indicating that couples are} not able to complete their fertility plans.

Fertility gaps are measured by comparing fertility intentions to fertility rates. Beaujouan and Berghammer (2019) calculate the fertility gap and excess childlessness for the cohort of women born in the 1970s across 19 European countries, finding that "while fertility rates are generally low in Europe, fertility intentions remain close to replacement level" (p. 508). One extreme of the fertility gap is excess childlessness, which refers to the number of women aged 20-24 who intended not to have children compared to the number of women who ended up without children by ages 40-42. Since the question about fertility intentions is asked to these women in their early twenties (specifically chosen as an age when they are likely to have completed their education), but completed fertility is not measured until their early forties, this seems like a classic case of stated preferences diverging from revealed preference. ${ }^{10}$ In other words, perhaps women tend to underestimate the marginal costs and/or overestimate the marginal benefits of children.

However, this an unsatisfactory explanation. First, if women are merely poor predictors of their own actual fertility, why do they systematically err in the same direction? If these trends could be attributable to lack of information, errors in judgement may be expected to cancel each other out (e.g., some women would discover that they like children more than they predicted). Second, the tendency of young women to over-predict their own fertility holds across drastically different political and economic institutions. Stone (2019) looks at fertility ideals across the globe and concludes that "most women around the world, even most women in countries outside of Europe and North America, are more likely to undershoot than overshoot their fertility ideals." If the fertility gap was primarily due to underlying economic or political variables, such a consistent pattern would be unusual. Finally, some of the women asked the question about fertility intentions already have children (restricting only on age), indicating that the fertility gap is not simply the result of women updating their priors after having their first child. The ubiquity of the fertility and childlessness gaps invites the consideration of external explanations.

One trend that has been affecting women all over the world in the past century is increasing political experimentation with "family policy" (Gauthier, 1996). Public choice scholars have un-covered a myriad of the unintended consequences of public policies; family policy is no exception. While there is still much work to be done, a few recent studies of specific U.S. regulations identify the consequences they might have for fertility. For example, Gorry and Thomas (2017) investigate the rising cost of child care and find that:

\footnotetext{
10 The specific question used by Beaujouan and Berghammer (2019) is: "(In addition to the child you are now expecting [pregnant]) how many (children of your own [childless]) (more children [parous]) do you want?'
} 


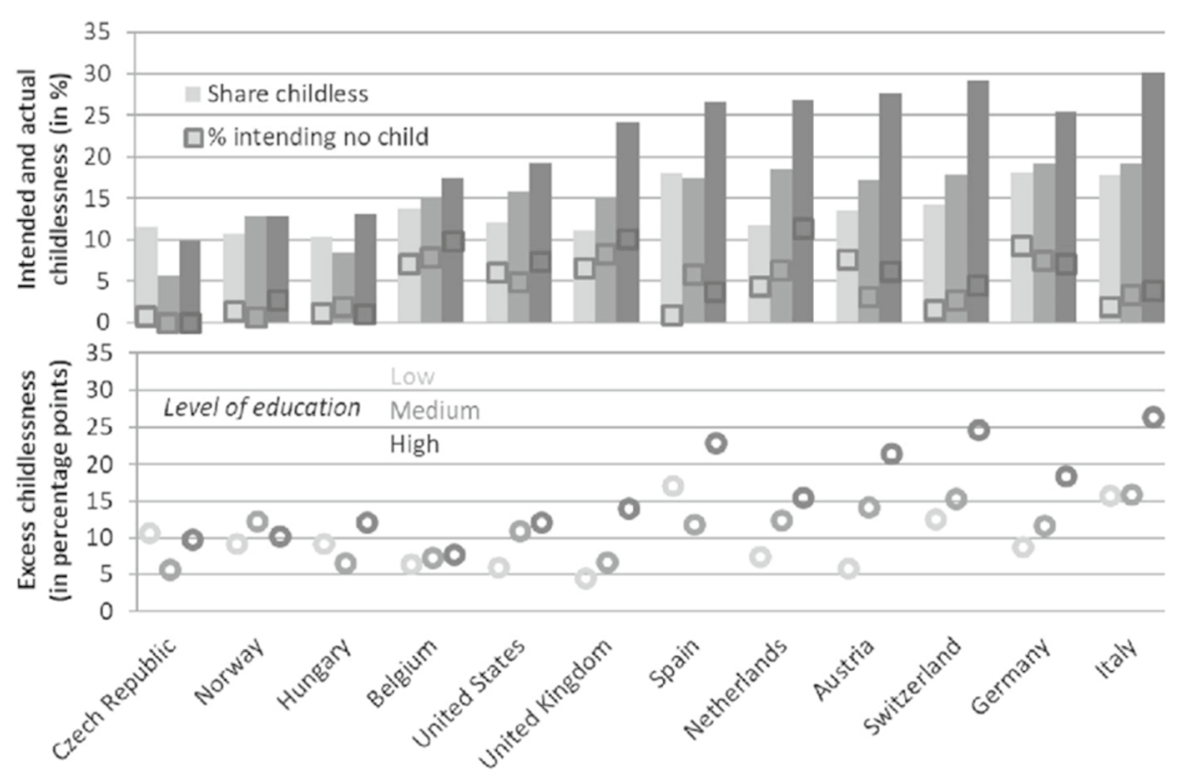

Fig. 4 Excess Childlessness in Select Countries, Decomposed by Educational Achievement of Women. Source: Fig. 4 in Beaujouan and Berghammer (2019).

- Regulations on child-staff ratios, group size restrictions, and education requirements are all associated with higher prices for childcare

- Such regulations are easily observable but do not necessarily increase the quality of care

In a similar vein, Nickerson and Solomon (2020) look at U.S. child car seat regulations that are intended to protect small children. They find that these regulations have unexpected, adverse effects on the fertility decisions of parents since they raise the cost of the marginal (often third) child by requiring parents to purchase new cars in order for all the car seats to fit. In particular, these regulations prevented just 57 car crash fatalities of children in 2017 while leading to a loss of over 3,500 births per year since 1980 (Nickerson \& Solomon, 2020). ${ }^{11}$

An important clue, perhaps, lies in the fact that the fertility gap is positively correlated with educational achievement. Figure 4 illustrates the excess childlessness experienced by women across several countries, decomposed by their level of education.

\footnotetext{
11 Another important aspect of unintended consequences concerns the funding for programs that might otherwise lower the cost of the marginal child. Sawhill (2006) examines the burden of U.S. federal debt upon future generations:" '\$156,000 in debt.' That's the amount that every American child already owes, on behalf of his or her country, if you add our $\$ 8.3$ trillion national debt, plus unfunded commitments to Medicare, Social Security and other entitlement programs..." It is worth noting that the socioeconomic groups where fertility rates are the lowest are also those bearing the highest tax rates.
} 
Since high educational attainment often brings with it a relatively higher income, why are the most advantaged women the least likely to fulfill their fertility plans? A theory of family policy could shed light on the matter. First, there might be distortions in the marriage market, leading to fewer opportunities for high-education women to fulfill their fertility plans. The subsidization of college (insofar as it distorts signals) and decline of other matching institutions in civil society may have a role to play in this (Kirkebøen et al., 2021). Second, recall that producing people (i.e., fertility) requires a substantial short-run sacrifice of labor. Labor is not homogeneous, however, even from the perspective of the state. Some groups have much greater average productivity than other groups. This means that state revenues and firm profits would be lower if those with higher productivity (e.g., highly skilled female workers) took time off to raise children (or even just needed more flexibility) than if those with lower productivity made the same decision. This fact also sheds light upon the anti-natal policies in both the Soviet Union and China which surprisingly allowed for exceptions amongst minority groups. Why would an autocratic regime encourage fractionalization? One key factor may be that labor from an educated majority is relatively more costly to sacrifice for long-run population growth than labor from relatively unskilled minority groups. Put differently, state actors try to shift the costs of population growth to the group with the lowest opportunity cost from the state's perspective. The group homes for poor, single mothers in Soviet Russia, designed to increase their fertility, are evidence of this as well.

\subsection{Pattern 2}

Family policy has historically been successful at lowering fertility rates but unsuccessful at increasing fertility rates.

Policymakers have long been responding to fears of declining fertility by promoting various policies which aim to increase childbearing and support for families (Gauthier, 1996). Such policies include direct cash transfers to families with children, tax relief for households with dependents, maternity and paternity leave, childcare and schools, and healthcare benefits. Hungary is a recent example, offering a loan of $\$ 30,000$ to qualifying couples that will not have to be repaid if the couple has at least three children. In the United States, "pro-family" policy bundles have recently been proposed by politicians in both parties.

What is notable about all of these policies, however, is that they have historically proved futile. Measures taken to reduce birth rates, on the other hand, have been so successful that they are often reversed in less than two generations. For example, the coercive anti-natal policies in China and India have skewed the world's sex ratio at birth to 107 boys per 100 girls (Follett, 2020). These policies have since been dismantled, with China increasing the permitted fertility for each family from one to two children in 2016, and since 2020, increasing this again to three. The case of 
Singapore is also illustrative in this regard. ${ }^{12}$ After a large propaganda campaign promoting their "Stop-at-Two" policy in 1966, the Singapore government replaced it with a "Have-Three-or-More (if you can afford it)" policy in 1987. Currently, Singapore's pro-natal policy package includes paid maternity leave, childcare subsidies, tax relief and rebates, cash gifts, and grants for companies that implement flexible work arrangements. Despite these efforts, their fertility rate dropped from 1.41 in 2001 to 1.16 in 2018, and Singaporeans still tend not to achieve their ideal family size (Call et al., 2008).

A theory of family policy can shed light on this unbalanced political track record. At their root, pro-natal policies face tougher knowledge and incentive problems than their anti-natal counterparts. Many factors contribute to a couple's decision to have a child: timing, religious beliefs, economic concerns, and of course, the heavy hand of nature. The tacit knowledge required to conceive, bear, and raise a child is perhaps the ultimate spontaneous order (which makes sense, given that the two most intimate relationships - the spousal and the parental - are at play in this process) (Hayek, 1945). As just one aspect of the complexity, consider how a new birth typically requires an agreement between both parties, and that it is quite common for one partner to desire another child while the other does not Doepke and Kindermann (2019). Moreover, the pill has plausibly altered the bargaining power between men and women, further reducing the incentive to bear children (Beauchamp \& Pakaluk, 2019).

One important influence on fertility and family in general that has not yet been addressed by this paper is religion. In contrast to governments, religious organizations seem to be good at encouraging fertility amongst their members (Baudin, 2015; Schnabel, 2021). While the role of religion is difficult to measure, recent work has found creative ways to estimate its effects, such as by comparing the fertility of couples who choose religious or traditional names for their children to those who choose names that are less conventional (Connor, 2021). Why are religions better than governments at promoting fertility? First, high-fertility religions (like Catholicism, Islam, and orthodox Judaism) also exhibit higher rates of marriage between their members, pointing to the fact that the "production process" of children begins long before they are conceived. Next, religious leaders are locally involved (often from the community) and able to provide specialized services to couples, such as organizing child care or marital counseling. Third, there is evidence that peer effects are important determinants for fertility, and religious communities can be seen as venues for high-fertility couples to influence the perceptions of couples considering whether or not to have a child (Edin \& Kefalas, 2011).

Barriers to fertility such as sterilization, abortion, financial penalties, or increasing the cost of marriage, on the other hand, are less costly to enforce than aids to fertility. This is because the aids required by couples vary widely (financial resources, job constraints, family proximity, etc.) and may not be not particular to fertility per

\footnotetext{
12 I am indebted to Peter Boettke for drawing my attention to this case during our conversations about Soviet family policy.
} 
say (e.g., financial aid can be spent elsewhere). ${ }^{13}$ Enforcing a restriction on the number of children has only become easier over time with modern abortion technology. Moreover, there is a serious measurement problem. The lack of children may be through no fault of the couple (thus more difficult to enforce), whereas pregnancy is obviously the result of an action taken by the couple. In short, less knowledge is required when enforcing a one-child rule than promoting a three-child rule.

Finally, we can turn to the demand side. There are good reasons to think that politicians gain more by gesturing at pro-natal policies than actually committing the resources to implement them. According to estimates by the Urban Institute, the federal government spent about $\$ 6,700$ per child (under 19) in 2019 , which constitutes $9 \%$ of the federal budget. State and local gov- ernments contribute twice as much (Hahn et al., 2020). "Pro-family" policies such as child tax credits, public schools, and family allowances would exacerbate the short-run revenue loss that states experience when mothers and fathers spend more time and resources on their children and fewer hours at work. The child will eventually grow up and contribute their and resources to the economy, of course, but these politicians will be out of office before they can experience these benefits. Recent work by Lyman (2020) sheds some light on this point. In particular, he points out that "hyper-targeted" pro-natal policies, such as in Hungary, have remained generally unsuccessful while broader, more generous policies, such as in Poland, exhibit better results. This means that policymakers must invest huge sums if they want to see rises in fertility: "Truth be told, trying to boost birth rates to replacement rate purely through cash incentives is prohibitively costly" (Lyman, 2020).

\subsection{Pattern 3}

\section{Central planners of economic life tend to be central planners of family life as} well.

Skarbek and Leeson (2009) define central planning (in the context of foreign aid) as the attempt to allocate resources without private property or market prices. Although central planners cannot discover the resource allocations that maximize their values, "like anyone else, central planners can increase a given output by devoting more resources to its production" (Skarbek \& Leeson, 2009, p. 392). States that fit this picture most closely are the large totalitarian regimes of the 20th and 21st century: the Soviet Union and People's Republic of China. International development agencies like USAID, the World Bank, and the IMF also qualify under this definition. Each of these organizations has extended its efforts to direct the economic life of individuals to their family life. The motivations behind family policies are complex and generally earnest, but a theory of family policy can help identify the role of special interests in concentrating benefits and dispersing costs through population control.

${ }^{13}$ I thank an anonymous reviewer for help on this point. 
First and most obviously, economic goals and fertility goals are inextricably linked. A basic reason for central planning in both spheres is that the labor and ideas of a population may be controlled through family policy. Family policy also gives centralized regimes greater control over competing claims to loyalty in civil society, like religion and social clubs, since these groups often have a symbiotic relationship with the family. Once family policies are introduced and state regulation of family life is established, special interest groups may sustain and increase these programs over time.

For example, in 1917 the Soviet Union became the first country in the world to legalize unilateral divorce and abortion. These policies were explicitly aimed at erasing the symbiotic relationship between the Russian Orthodox church and the $d v o r$, or intergenerational Russian family: "The complete break of the state power with canonical, religious, ecclesiastical views on marriage makes it possible to free the masses in this respect from the oppression of the priest- hood" (Goikhbarg, "Marital, Family Guardianship Law," 1920). Subsequent years brought many attempts by the state to centralize aspects of family life: public education, communal kitchens, state daycare, and numerous youth organizations that occupied the free time of children and func- tion as centralized marriage markets. The evidence is overwhelming that the early Soviet state viewed private cooperation between family members, especially concerning the rearing of children, as detrimental to the power of the Party. Figes (2007) provides many such accounts. By intro- ducing policies that reduced familial production, the Party was able to transfer security, control, and loyalty to themselves.

A similar story has played out in China. The CCP's One Child Policy was introduced in 1979 after generations of tumultuous state intervention in private life. The documentary "One Child Nation" (Zhang \& Wang, 2019) provides many first-hand accounts about the coercion necessary to fulfill this policy (as well as predictable underground activity). Zhang (2017) analyzes the causes and consequences of China's move from Mao Zedong's principle, "More people, more power," to the One Child Policy. Zhang (2017) concludes:

Although the enforcement of the one-child policy may have mildly accelerated the fertility transition in China, it also brought substantial costs, including political costs, human rights concerns, a more rapidly aging population, and an imbalanced sex ratio resulting from a preference for sons. In retrospect, one may question the need for introducing the one-child policy in China (p. 156).

Finally, consider the various population control policies and methods espoused by interna- tional development agencies. Although there are significant differences between these organizations and the previous two cases, this is still a case that illustrates how the central planning of economics and families goes hand in hand. One needs to go no further than Simon to find out the special interests at play on the international stage. For instance, Simon (1990) does not shy away from making a list of the organizations with financial stake in population "control," or rather, reduction. Kasun (1988) describes recent cases in which the U.S. has explicitly tied aid to population control outcomes. For instance: 
A sterilization drive in El Salvador, financed by the U.S. Agency for International De- velopment (USAID), "motivates" providers and acceptors by a quota system and elicits complaints of inadequate requirements for voluntary consent...in Bangladesh a United States financed health project links birth control with oral rehydration treatment for children with diarrhea. The treatment for the sick infants serves as the "incentive" for their parents to "accept" birth control (Kasun, 1988, p.5).

She explains how these internationally unpopular policies carry high costs for the international reputation of the U.S., especially in countries like Iran and the Philippines. Moreover, Kasun (1988) notes that "why and how such things can happen is a study in the economic of public decision making in the era of massive and growing government budgets" (p. 5). U.S. taxpayers began funding these initiatives in the Johnson administration, but they have drastically expanded since. Efforts toward population reduction on the ground also exhibit predictable features, such as motivating clients with money rewards to demonstrate need for increased funds. Kasun (1988) addresses the several groups exerting "special interest control" over public policy regarding family planning, of course, none of whom are elected: International Planned Parenthood, the Population Council, USAID, and some centers in American universities.

Scholars familiar with the research of Julian Simon will not be surprised by the fact that the more a governance organization intervenes in the market economy - as demonstrated through the extreme cases above - the more it will also intervene in family life. While the market uses prices and relies on anonymous cooperation, and the family uses conversation and relies on intimate cooperation, market actors and family members allocate resources to their most highly valued uses in a harmonious, decentralized manner. Both are limits to state power.

\section{Conclusion}

Julian Simon may have been pleased to learn fertility intentions are not currently holding fertility in much of the world below replacement, but rather frustrated fertility intentions. However, I do not think that he or other mainline economists would be surprised. If Hayek (1945) is right, then it is primarily the family, and the state, which understands the extent to which "people are the ultimate resource."

This paper discussed and applied three principles toward of a theory of family policy: fam- ilies produce people, people have ideas, and people production is a private enterprise. Three patterns in past and present family policy - fertility gaps, the failures of pro-natal policy and suc- cessful anti-natal policy, and the tendency of central planners to control fertility - are illuminated by a marriage of insights from both family economics and public choice. In doing so, I hope this paper honors the memory of Julian Simon:

I believe that helping a couple get the number of children that the couple wants is one of the great works of humanity. And to the extent that governments do just that, I generally support their activities. It is only when they conduct a 
coercive or propagandistic population-control program under the false label of 'family planning' that I do not support the activity; it then is a limitation of peoples' liberties rather than an extension of their capacities (1996).

\section{Appendix}

The following is an unpublished manuscript from the James Buchanan Archives at George Mason University:

Marriage and Opportunity Cost by

James M. Buchanan University of California Los Angeles

Professor Gary North may or may not have been serious in final intent when he applied opportunity- cost reasoning to the choice of marriage partners. ${ }^{14}$ But presumably his analysis was presented as a correct application of "fundamental principles." He labels his treatment as that which appears in elementary textbooks. Unfortunately, he makes the same error that is found in many of these.

Perhaps North's confusion stems simply from masculine vanity, but seriously interpreted his discussion reflects a pervasive error in opportunity-cost discussion. This is the implicit objectifica- tion of cost, with an accompanying failure to relate cost explicitly to the choices that are made. ${ }^{15}$ In this instance, North suggests that his friend, the academic historian, bears the opportunity- cost represented in the discounted potential earnings stream of his professionally-trained wife, the physicist Ph.D. Furthermore, North implies that the historian might make an alternative marital selection if he has taken sophomore economics. This is incorrect. The opportunity cost that influ- ences choice is that estimate of the benefits that must be given up on taking one course of action rather than another. The historian contemplating marriage does not sacrifice his prospective wife's future market earnings when he chooses her over her competitors. Only if he has, and in some fashion independently of the marriage contract, acquired a property right in this particular female can he suffer such a cost. His choice as between the female physicist and the hausfrau is that between acquiring assets valued quite differently by the market despite their availability to him on negligibly different terms. It would be irrational for him deliberately to select the lower-valued asset, regardless of his intended use.

North's logic has relevance, of course, but only to the choice that the professionally-trained potential wife faces. To the extent that she makes accurate predictions about her own future earning power in the market, she must suffer the opportunity cost that North stresses. The historian can rest assured that he is shrewder than North's sophomore students who have mastered their principles of economics. His wife should not be allowed access to this issue of this journal.

\footnotetext{
14 “A Note on the Opportunity Cost of Marriage," Journal of Political Economy, 76 (March/April, 1968), 321-23.

15 Relatively little modern analysis escapes this error. Emphasis on a "correct" definition of cost characterizes only the works of a combined A[us]trian-London tradition, notably in the works of Robbins, Hayek, Mises, Coase, Thirlby, Wiseman, and Kirzner. This tradition, along with some of the implications for economic policy discussion, is examined in detail in my Cost and Choice (forthcoming).
} 


\section{References}

Agostinelli, F., Doepke, M., Sorrenti, G., \& Zilibotti, F. (2020). When the great equalizer shuts down: Schools, peers, and parents in pandemic times (no. w28264). National Bureau of Economic Research.

Aligica, P. D. (2009). Julian simon and the 'limits to growth' neo-malthusianism. The Electronic Journal of Sustainable Development, 1(3), 73-84.

Baudin, T. (2015). Religion and fertility: The french connection. Demographic Research, 32, $397-420$.

Beauchamp, A., \& Pakaluk, C. R. (2019). The paradox of the pill: Heterogeneous effects of oral contraceptive access. Economic Inquiry, 57(2), 813-831.

Beaujouan, E., \& Berghammer, C. (2019). The gap between lifetime fertility intentions and completed fertility in europe and the united states: A cohort approach. Population Research and Policy Review, $38,507 a ̂ 535$.

Becker, G. S. (1981). A Treatise on the Family. Harvard University Press.

Becker, G., \& Murphy, K. (1988). The family and the state. Journal of Law and Economics, 31, 1-18.

Becker, G. S., Murphy, K. M., \& Grossman, M. (2006). The market for illegal goods: The case of drugs. Journal of Political Economy, 114(1), 38-60.

Becker, G. S., Murphy, K. M., \& Topel, R. H. (2011). On the economics of climate policy. The BE Journal of Economic Analysis Policy, 10(2).

Boettke, P. J., \& Lopez, E. J. (2002). Austrian economics and public choice. The Review of Austrian Economics, 15, 2/3:111â119.

Boudreaux, D. J. (2008). The ultimate scholar. TribLive. https://archive.triblive.com/news/the-ultimatescholar/.

Boudreaux, D. J. (2011). More weather deaths? wanna bet? Wall Street Journal. https://www.wsj.com/ articles/SB10001424052702304520804576346051736171090.

Breton, A. (1989). The growth of competitive governments. Canadian Journal of Economics, 22, 717-750.

Brinig, M. F. (2000). From contract to covenant: Beyond the law and economics of the family. Harvard University Press.

Buchanan, J. M., \& Wagner, R. E. (1977). Democracy in deficit â The political legacy of Lord Keynes. Academic Press.

Buckles, K. S., \& Munnich, E. L. (2012). Birth spacing and sibling outcomes. Journal of Human Resources, 47(3), 613-642.

Call, L. L., Sheffield, R., Trail, E., Yoshida, K., \& Hill, E. J. (2008). Singapore's falling fertility: Exploring the influence of the work-family interface. International Journal of Sociology of the Family, 34, 91-113.

Caplan, B. (2011). The julian simon club. EconLog.

Chetty, R., Friedman, J. N., Hendren, N., Jones, M. R., \& Porter, S. R. (2018). The opportu- nity atlas: Mapping the childhood roots of social mobility (no. w25147). National Bureau of Economic Research.

Connor, D. (2021). In the name of the father? fertility, religion and child naming in the demo- graphic transition.

DeAngelis, C., \& Makridis, C. (2020). Are school reopening decisions related to union influence? Available at $\operatorname{SSRN} 3684867$.

Derrien, F., Kecskes, A., \& Nguyen, P.-A. (2020). Labor force demographics and corporate innovation. HEC Paris Research Paper No. FIN-2017-1243.

Doepke, M., \& Kindermann, F. (2019). Bargaining over babies: Theory, evidence, and policy implications. American Economic Review, 109(9), 3264-3306.

Doyle, O., Harmon, C., Heckman, J. J., Logue, C., \& Moon, S. (2013). Measuring investment in human capital formation: An experimental analysis of early life outcomes (no. w19316). National Bureau of Economic Research.

Ediev, D. (2001). Application of the demographic potential concept to understanding the russian population history and prospects: 1897-2100. Demographic Research, 4, 289-336.

Edin, K., \& Kefalas, M. (2011). Promises I can keep: Why poor women put motherhood before marriage. Univ of California Press.

Figes, O. (2007). The Whisperers: Private Life in Stalin's Russia. Picador. 
Follett, C. (2020). Neo-Malthusianism and Coercive Population Control in China and India: Overpopulation Concerns Often Result in Coercion. Policy Analysis No. 897, Washington, DC.: Cato Institute. https://doi.org/10.36009/PA.897.

Frejka, T., \& Zakharov, S. (2013). The apparent failure of russiaâs pronatalist family policies. Population and Development Review, 39(4), $635 a ̂ 647$.

Gauthier, A. H. (1996). The state and the family: A comparative analysis of family policies in industralized countries. Clarendon Press.

Gorry, D., \& Thomas, D. W. (2017). Regulation and the cost of childcare. Applied Economics, 49(41), 4138-4147.

Greenwood, J., Guner, N., \& Marto, R. (2021). The great transition: Kuznets facts for family-economists (no. w28656). National Bureau of Economic Research.

Hahn, H., Lou, C., Isaacs, J. B., Lauderback, E., Daly, H., \& Steuerle, C. E. (2020). Kids' share 2020: Report on federal expenditures on children through 2019 and future projections. Urban Institute.

Hall, L. K. (2014). Family and the politics of moderation: Private life, public goods, and the rebirth of social individualism. Baylor University Press.

Hayek, F. A. (1945). The use of knowledge in society. The American Economic Review, 35(4), 519-530.

Holcombe, R. G. (2009). Product differentiation and economic progress. Quarterly Journal of Austrian Economics, 12(1), 17-35.

Holmes, J., \& Tiefenthaler, J. (1997). Cheaper by the dozen? the marginal time costs of children in the philippines. Population Research and Policy Review, 16(6), 561-578.

Horwitz, S. (2015). Hayek's modern family: Classical liberalism and the evolution of social insti-tutions. Palgrave Macmillan.

Hoxby, C. M. (2003). School choice and school productivity. could school choice be a tide that lifts all boats? the economics of school choice (pp. 287-342). University of Chicago Press.

Jacobsen, P. (2020). The political economy of the ultimate resource: Essays on institutions and entrepreneurship. Doctoral dissertation, George Mason University.

Jennings, M. K., \& Niemi, R. G. (1968). The transmission of political values from parent to child. The American Political Science Review, 62(1), 169-184.

Jones, C. I. (2020). The end of economic growth? unintended consequences of a declining popu-lation (pp. 1-44). Stanford GSB and NBER.

Karahan, F., Pugsley, B., \& Åahin, A. (2019). Demographic origins of the startup deficit (no. w25874). National Bureau of Economic Research.

Kasun, J. R. (1997). Government family planning: Effects and incentives. The Review of Austrian Economics, 10(2), 47-76.

Kasun, J. R. (1999). The war against population: The economics and ideology of world population control. Ignatius Press.

Kasun, J. R. (1978). A reply to zero population growth. Society, 15(4), 9-9.

Kasun, J. R. (1988). Gnats and camels: Congressional oversight of population programs. Society.

Kirkebøen, L., Leuven, E., \& Mogstad, M. (2021). College as a marriage market (No. w28688). National Bureau of Economic Research.

Lakshminarayanan, R. (2007). Population issues in the 21st century: The role of the world bank. Health.

Leeson, P. T., \& Pierson, J. (2017). Economic origins of the no-fault divorce revolution. European Journal of Law and Economics, 43(3), 419-439.

Lerman, R. I. (1996). The impact of the changing us family structure on child poverty and income inequality. Economica, 63, S119-S139.

Liang, J., Wang, H., \& Lazear, E. P. (2018). Demographics and entrepreneurship. Journal of Political Economy, 126(S1), S140-S196.

Lino, M., Kuczynski, K., Rodriguez, N., \& Schap, T. (2014). Expenditures on children by families, 2013. Center for Nutrition Policy and Promotion, US Department of Agriculture.

Lyman, S. (2020). Pro-natal policies work, but they come with a hefty price tag. Institute for Family Studies.

Mueller, D. C. (2003). Public choice III. Cambridge University Press.

Murphy, K. M., \& Topel, R. H. (2006). The value of health and longevity. Journal of Political Economy, 114(5), 871-904.

Nickerson, J., \& Solomon, D. H. (2020). Car seats as contraception. Available at SSRN 3665046.

Pakaluk, C. R. (2021). What good is a good fit? religious matching and educational outcomes. Cosmos+Taxis, 9(1+2), 3-30.

Peterson, J. (1987). The feminization of poverty. Journal of Economic Issues, 21(1), 329-337. 
Sawhill, I. R. (2006). Debt is cheating our childrenâs future. Brookings.

Schnabel, L. (2021). Secularism and fertility worldwide. Socius, 7, 23780231211031320.

Scott, J. C. (2020). Seeing like a state: How certain schemes to improve the human condition have failed. Yale University Press.

Simon, J. L. (1977). The economics of population growth. Princeton University Press.

Simon, J. L. (1990). The population establishment, corruption, and reform. In G. Roberts (Ed.), Population policy: Contemporary issues. Praeger.

Simon, J. L. (1993). Economic thought about population consequences: Some reflections. Journal of Population Economics, 6, 137-152.

Simon, J. L. (1996). The ultimate resource: 2. Princeton University Press.

Skarbek, D. B., \& Leeson, P. T. (2009). What can aid do? Cato Journal, 29, 391.

Stone, L. (2019). The global fertility gap. Institute for Family Studies Blog.

Wolfinger, N. H., \& Wolfinger, R. E. (2008). Family structure and voter turnout. Social Forces, 86(4), $1513-1528$.

Zhang, J. (2017). The evolution of china's one-child policy and its effects on family outcomes. Journal of Economic Perspectives, 31(1), 141-160.

Zhang, J., \& Wang, N. (2019). One Child Nation. Amazon Studios.

Hayek, F. A. (1989). The collected works of FA Hayek (Vol. 6). University of Chicago Press.

Publisher's note Springer Nature remains neutral with regard to jurisdictional claims in published maps and institutional affiliations. 